\title{
Bowhead whale Balaena mysticetus diving and movement patterns in the eastern Canadian Arctic: implications for foraging ecology
}

\author{
Corinne Pomerleau ${ }^{1,2, *}$, Toby A. Patterson ${ }^{3}$, Sebastian Luque ${ }^{4}$, Véronique Lesage ${ }^{5}$, \\ Mads Peter Heide-Jørgensen ${ }^{6}$, Larry L. Dueck ${ }^{7}$, Steven H. Ferguson ${ }^{7}$ \\ ${ }^{1}$ Fisheries \& Oceans Canada, Institute of Ocean Sciences, Sidney, British Columbia V8L 4B2, Canada \\ ${ }^{2}$ Université du Québec à Rimouski, Rimouski, Quebec G5L 3A1, Canada \\ ${ }^{3}$ CSIRO Wealth from Oceans Research Flagship, Hobart, Tasmania 3169, Australia \\ ${ }^{4}$ Department of Biological Sciences, University of Manitoba, Winnipeg, Manitoba R3T 2N2, Canada \\ ${ }^{5}$ Fisheries and Oceans Canada, Maurice Lamontagne Institute, Mont-Joli, Quebec, G5H 3Z4, Canada \\ ${ }^{6}$ Greenland Institute of Natural Resources, Greenland 3900, Denmark \\ ${ }^{7}$ Fisheries and Oceans Canada, Freshwater Institute, Winnipeg, Manitoba R3T 2N2, Canada
}

\begin{abstract}
The bowhead whale Balaena mysticetus is the only mysticete species endemic to the Arctic. The Eastern Arctic-West Greenland (EA-WG) population is considered of special concern in Canada as these whales remain at risk of becoming threatened or endangered due to their slow rate of growth and low fecundity, and ongoing environmental changes in the Arctic. In this context, we used satellite-linked time-depth recorders (SDR-T16) to investigate their movements and dive behaviour and identify plausible summer feeding areas in the Canadian Arctic. Seven individuals from the northern Foxe Basin (FB) ( $\mathrm{n}=4$ in July 2003) and Cumberland Sound (CS) ( $\mathrm{n}=3$ in July 2006) were tracked by satellite for 17 to $293 \mathrm{~d}$. Movement patterns from 4 whales were analyzed using a hidden Markov model (HMM) to inform the probability of whales being in one of 2 behavioural modes: transient or resident. Comparing dive characteristics during transient and resident periods, we observed that the Gulf of Boothia (GB) with moderate ice coverage (54-62\%) was used as a summer foraging area by all 4 whales even though they came from different regions. All animals transited rapidly through Fury and Hecla Strait, an area of heavy ice coverage $(80-98 \%)$. Whales spent most of their time at shallow depths $(8-16 \mathrm{~m})$ regardless of time of day when in resident mode, likely feeding on near-surface aggregations of zooplankton. Considering the apparent importance of the GB as a feeding area for this population, every effort should be made to maintain the integrity of this ecosystem.
\end{abstract}

KEY WORDS: Bowhead whale $\cdot$ Balaena mysticetus $\cdot$ Movement $\cdot$ Diving behaviour $\cdot$ Hidden Markov model $\cdot$ Foraging habitat $\cdot$ Sea ice

Resale or republication not permitted without written consent of the publisher

\section{INTRODUCTION}

The bowhead whale Balaena mysticetus is the only mysticete whale endemic to the Arctic (Nowak \& Walker 2003). The species occurs in Canadian waters as 2 separate populations: the BeringChukchi-Beaufort (BCB) and the Eastern CanadaWest Greenland (EC-WG) populations. Although commercial whaling severely depleted both populations during the 15th to 19th centuries (Woodby \& Botkin 1993), recent abundance estimates show evidence of increase for these populations (Koski et al. 2006, Dueck et al. 2007, Heide-Jørgensen et al. 2007, IWC 2009).

Both populations are considered of 'Special Concern' in Canada, as they are still considered at risk of 
becoming threatened or endangered (COSEWIC 2009). However, factors affecting their abundance, distribution and foraging ecology are only beginning to be understood. This long-lived species (>200 yr) is sexually mature at around $25 \mathrm{yr}$ of age, and has a low fecundity combined with long inter-birth interval (George et al. 1999). These particular biological characteristics make this species more vulnerable to the effects of climate change, to increasing killer whale predation and to the impacts of human activities (e.g. shipping, mining, oil and gas field exploitation), especially those occurring near or within their feeding or nursery areas (IPCC 2007, Higdon \& Ferguson 2009).

Previous studies on movements of EC-WG bowhead whales have shown that these animals are widely distributed throughout the Canadian eastern Arctic and West Greenland where they perform long seasonal migrations (Heide-Jørgensen et al. 2003). Their winter distribution includes Hudson Strait, northern Hudson Bay, east Baffin Island and the ice edge along West Greenland (Reeves \& Heide-Jørgensen 1996, Koski et al. 2006), while in spring they are usually found along the west coast of Greenland, in Cumberland Sound (CS), Foxe Basin (FB) and Lancaster Sound (Fig. 1). Their summer range includes the fjords and bays of the Canadian High Arctic, Hudson Bay and FB (Cosens et al. 1997, Cosens \& Innes 2000, Higdon \& Ferguson 2010).

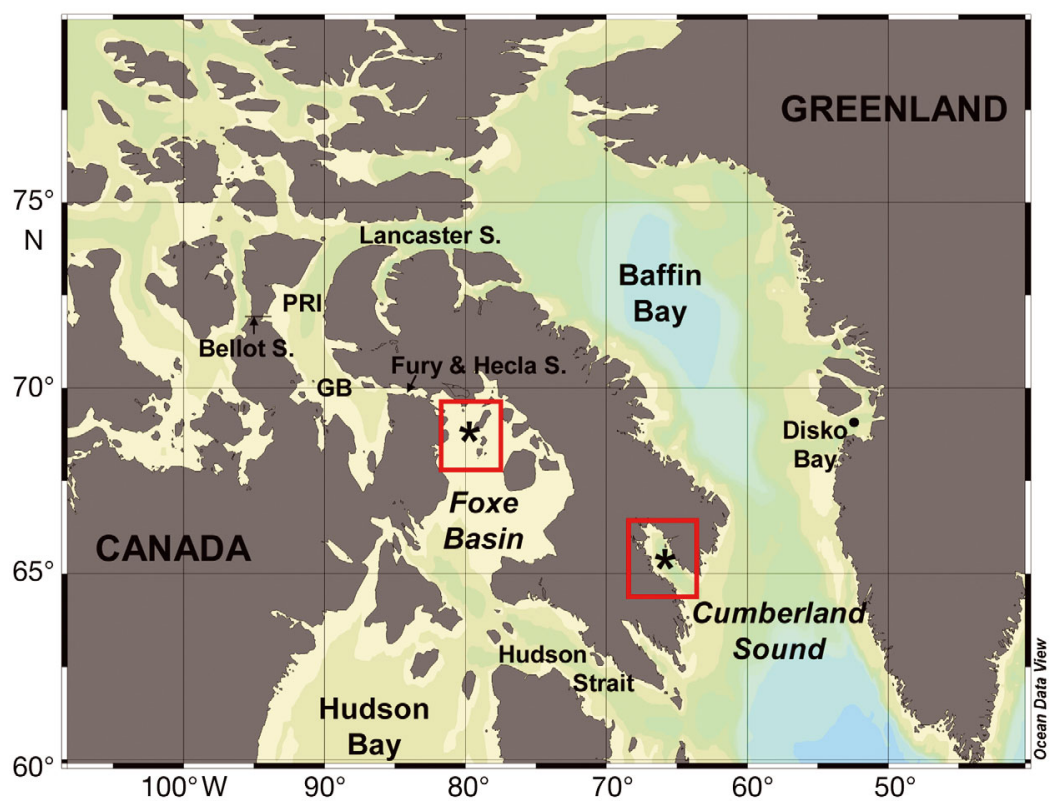

Fig. 1. Bowhead whale tagging locations in the eastern Canadian High Arctic (red rectangles), in Foxe Basin in 2003 and Cumberland Sound in 2006. $\mathrm{GB}=$ Gulf of Boothia; PRI $=$ Prince Regent Inlet
Bowhead whales are assumed to feed on pelagic and epibenthic zooplankton in late summer and fall (Finley 2001, Lowry et al. 2004, Pomerleau et al. 2011), and on pre-ascending diapausing calanoid copepods in late winter and early spring, at least in Disko Bay, Greenland (Laidre et al. 2007). Although bowhead whale movement patterns and diet have been studied previously, where and when they feed across the vast eastern Arctic remains poorly understood (Higdon \& Ferguson 2010, Kovacs et al. 2010). Most studies on foraging behaviour of bowhead whales from the East Arctic-West Greenland (EAWG) population have been based on observations of feeding, inferences from plankton net tow, shortduration dive data or a combination of these approaches (Finley 2001, Lowry et al. 2004, Lee et al. 2005, Laidre et al. 2007). The Arctic climate leads to large-scale seasonal shifts in both primary and secondary production, which are highly patchy in space and time. Although Arctic species are adapted to this variability, for instance by rapid accumulation of large blubber stores in the case of whales, the adaptability of species, such as bowhead whales, living exclusively at high latitude may be impaired by the ongoing warming climate (Neibauer \& Schell 1993). Thus, it is pressing to gain a better understanding of the factors affecting their abundance, distribution and foraging ecology.

Sea ice strongly influences the seasonal distribution of bowhead whales (Moore \& Reeves 1993, Dyke et al. 1996, Ferguson et al. 2010a). Whales appear to select areas of lower ice concentration and thickness during winter, likely to reduce risks of ice entrapment. The reverse is observed during summer, possibly to reduce exposure to predators such as killer whales, and increase feeding opportunities near the productive marginal sea ice zone (Gosselin et al. 1997, Ferguson et al. 2010a). The decreasing trend in Arctic sea ice extent and quality (Gagnon \& Gough 2005) is expected to have profound effects on habitat use and movement patterns of bowhead whales, as well as other Arctic species. Warming ocean temperatures affect plankton abundance and distribution (Greene \& Pershing 2007). The dependence of bowhead whales on zooplankton as a food resource (Pomerleau et al. 2011) may leave them vulnerable to changes in plankton availability (Pershing et al. 2009). 
Here, we use a recently developed technique, a 2state hidden Markov model (HMM), to gain insights into the location and characteristics of summer feeding areas of EC-WG bowhead whales. By combining dive and movement data in this analysis for 4 individual whales tracked remotely via satellite, we identified resident and transit modes and determined whether diving behaviour differed between resident and transit periods. Bowhead whales in resident mode are expected to be associated with sea ice. Diving depths during that mode should reflect feeding, although other behaviours can not be excluded. Since time of day influences the vertical distribution of planktivorous marine mammal prey species in most of the world's oceans (Benoit-Bird et al. 2009), we also examined diel variation in dive behaviour of bowhead whales.

\section{MATERIALS AND METHODS}

\section{Telemetry}

Individual bowhead whales from northern FB (2003) and CS (2006) were equipped with SDR-T16 satellite-linked time-depth recorders (Wildlife Computers), using an $8 \mathrm{~m}$ long fiberglass pole (Fig. 1). The tags deployed in FB were float tags tethered $1 \mathrm{~m}$ behind the whales and anchored with a harpoon head in the blubber (Heide-Jørgensen et al. 2003). These instruments provided information on date, time and location, as well as a summary of dive characteristics. Platform Transmitter Terminals (PTTs) had an estimated longevity of 20000 transmissions, and were programmed to relay positions and dive data every day.

\section{Analysis of movements}

The raw Argos location estimates were corrected using a hybrid speed filter/Kalman filter approach (Patterson et al. 2010). This method corrects for Argos error and produces a set of locations at regular intervals, which were chosen to be every $4 \mathrm{~h}$. The resulting positions were used to construct time series of speed of travel and turning angle between successive observations. These were analyzed using a 2state HMM (Patterson et al. 2009) to classify the bowhead whale movements into 2 putative movement modes, which we labeled 'transit' and 'resident'. Step lengths between locations and turning angles, conditioned on the hidden behavioural state, were modeled by a Weibull and a wrapped Cauchy distribu- tion, respectively. The HMMs were used to produce posterior probability distributions of state and the most likely state. The HMM output was then used in the diving analyses in order to contrast dive characteristics during transit and resident periods.

To test the influence of habitat on behaviour, we used a second model where the probability of switching between states was assumed to be a linear function of ice concentration. Mean ice concentration from 2 degree boxes centered on each location point was obtained from the Weekly NOAA Optimum Interpolation (OI) SST V2 product (Reynolds 1988) that uses in situ and satellite sea-surface temperatures (SST) as well as simulated SST to estimate seaice cover.

\section{Analysis of diving behaviour}

The raw pressure sensor data were summarized onboard the tag into 6-h blocks (03:00-09:00, 09:00-15:00, 15:00-21:00 and 21:00-03:00 h local time; set at the release location), and included information on dive depth, dive duration, and time-atdepth (TAD) (Table 1). The average diving depth and duration for each period were calculated by multiplying the mid-range depth or duration of each bin by the number of dives in that bin, adding the products across all bins, and dividing the result by the total number of dives in that period. Maximum diving depth and duration for each period were defined as the mid-range value of the rightmost histogram bin (deepest or longest dive) with at least 1 dive. We investigated whether there were diurnal cycles and inter-individual differences in diving depth, and relationships with behavioural state as estimated from HMM by first decomposing time into sine and cosine angular coordinates for time of day (Bell 2008). A series of linear models with additive effects for these components were fitted to test for the existence of these cycles in average and maximum diving depth, considering the following full model:

$$
Y=\beta_{1}+\beta_{2} \sin _{\mathrm{TOD}}+\beta_{3} \cos _{\mathrm{TOD}}+\beta_{4} \mathrm{I}+\beta_{5} \mathrm{M}+\varepsilon
$$

where $Y$ represents maximum or mean diving depth of an individual whale, $\sin _{\mathrm{TOD}}$ and $\cos _{\mathrm{TOD}}$ are the angular coordinates of time of day (TOD) in a $24 \mathrm{~h}$ cycle, and I is an indicator for the effect of individual, and $\mathrm{M}$ is the behavioural state from HMM. $\beta_{i}$ are model coefficients to be estimated, and $\varepsilon$ is residual error. The subset of candidate models consisted of all combinations of fixed effects from the full model where the angular coordinates, i.e. sine and cosine, 
Table 1. Summary information of bowhead whales tagged in Foxe Basin (FB) and Cumberland Sound (CS), showing data available $(\boldsymbol{})$ and not available (na) for the analyses. PTT $=$ Platform Transmitter Terminal; HMM = hidden Markov model analysis

\begin{tabular}{|ccccccccccc|}
\hline PPT no. & $\begin{array}{c}\text { Tagging } \\
\text { date }\end{array}$ & $\begin{array}{c}\text { Total no. of } \\
\text { transmissions }\end{array}$ & Location & Sex & $\begin{array}{c}\text { Length } \\
(\mathrm{m})\end{array}$ & $\begin{array}{c}\text { Dive } \\
\text { depth }\end{array}$ & $\begin{array}{c}\text { Dive } \\
\text { duration }\end{array}$ & $\begin{array}{c}\text { Time-at } \\
\text { depth }\end{array}$ & $\begin{array}{c}\text { HMM } \\
\text { Diurnal } \\
\text { pattern }\end{array}$ \\
\hline 20160 & 5 July 2003 & 71 & FB & F & 15 & $\checkmark$ & $\checkmark$ & $\checkmark$ & na & na \\
20167 & 8 July 2003 & 602 & FB & M & 13 & $\checkmark$ & $\checkmark$ & $\checkmark$ & $\checkmark$ & $\checkmark$ \\
21802 & 11 July 2003 & 673 & FB & F & 13 & $\checkmark$ & $\checkmark$ & $\checkmark$ & $\checkmark$ & $\checkmark$ \\
26712 & 18 July 2003 & 140 & FB & F & 12 & $\checkmark$ & $\checkmark$ & $\checkmark$ & $\checkmark$ & $\checkmark$ \\
66352 & 11 July 2006 & 716 & CS & F & 11 & $\checkmark$ & $\checkmark$ & na & na & na \\
66353 & 11 July 2006 & 1208 & CS & M & 12 & $\checkmark$ & $\checkmark$ & $\checkmark$ & $\checkmark$ & na \\
66356 & 5 August 2006 & 568 & CS & M & 12 & $\checkmark$ & na & na & na & na \\
\hline
\end{tabular}

were both included or excluded, as both are required to properly interpret cycles (Bell 2008). Thus, a total of 8 models for each response variable, average and maximum diving depth, were considered candidates (Table A1 in the Appendix). Dive duration was not included in analyses because it is strongly correlated with dive depth (Kooyman \& Ponganis 1998). The second-order Akaike Information Criterion (AICc) was calculated for each model, and the AICc differences $(\triangle \mathrm{AICC})$ were used to select the best model from the candidate set (Burnham \& Anderson 2002). Models were fit using the generalized least squares method implemented in the nonlinear mixed effects GNU R package (Pinheiro et al. 2011), where the observations for each individual were assumed to have a first-order autocorrelation structure.

\section{RESULTS}

\section{Movement patterns}

Seven bowhead whales were tagged in 2003 and 2006: 4 females ( 2 with calves), and 3 males. Three females and 1 male were tagged in FB near the community of Igloolik, and the other 3 individuals were tagged in CS in south-eastern Baffin Island. Each whale was identified by an individual PTT number (Table 1, Fig. 1). Only 4 whales, including 3 from FB and one from CS (66353), were used in the 2-state HMM for analysis of their movements. Reasons for short duration transmissions may be diverse, and include tag position on the whale and animal surface behaviour, i.e. height above water and pattern of immergence, PTT transmission versus satellite pass programming. Despite sample size limitations, broad-scale movement patterns were similar in all 4 whales even though tagging regions were separated by several hundreds of kilometres (Fig. 2). All whales traveled through Fury and Hecla strait, and spent time, most probably foraging, in the Gulf of Boothia (GB) (Fig. 1).

There was little difference ( 2 to $3 \%$ ) in the state prediction between the model implemented with and without sea ice. As a result, we provide the more parsimonious results from the simple model in the next section, with the qualitative effect of sea ice on behaviour.

For 4 whales, residency was displayed mainly in the northern part of GB and lasted from 2 wk to 2 mo. Mean sea ice cover in this presumed foraging area ranged from 54 to $62 \%$ between the end of July and mid-August and from 24 to $83 \%$ from September to mid-November. Residency also occurred in the northern part of FB but lasted for shorter periods, i.e. from 1 to $10 \mathrm{~d}$, and mean sea ice cover ranged from 40 to $45 \%$ in July. The whale with the longest track (66353) also displayed residency in CS both in July (mean sea ice cover: 12 to $36 \%$ ) and between early January and the end of April (mean sea ice cover: 64 to $93 \%$ ) (Fig. 2).

Animals departed from their tagging region (FB or CS) 1 to $7 \mathrm{~d}$ after tagging, arriving in the vicinity of GB between mid-July and early September. Maximum travel speeds ranged from 5 to $8 \mathrm{~km} \mathrm{~h}^{-1}$ depending on whale (Fig. 2a). Most tags failed in early August. The longest track available was from a CS individual, which spent time in CS areas of much lower ice cover (Table 2) before moving into FB for a period of residency during August, then to GB for September to November. This whale departed from GB via Prince Regent Inlet (PRI) in the first week of November when the ice cover was about $80 \%$ both in PRI and the other possible exit, the Fury and Hecla Strait. The whale circumnavigated Baffin Island via Lancaster Sound and Baffin Bay, and travelled into extensive ice-covered areas (up to $95 \%$ coverage) at speeds up to $12 \mathrm{~km} \mathrm{~h}^{-1}$ 


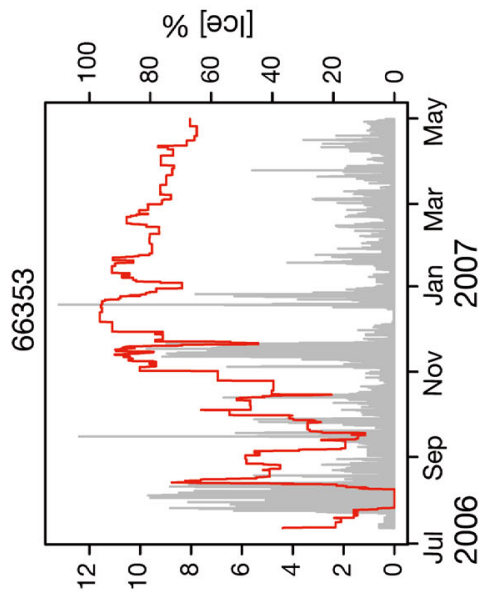

(pe^) ә|бue 6u!uın」

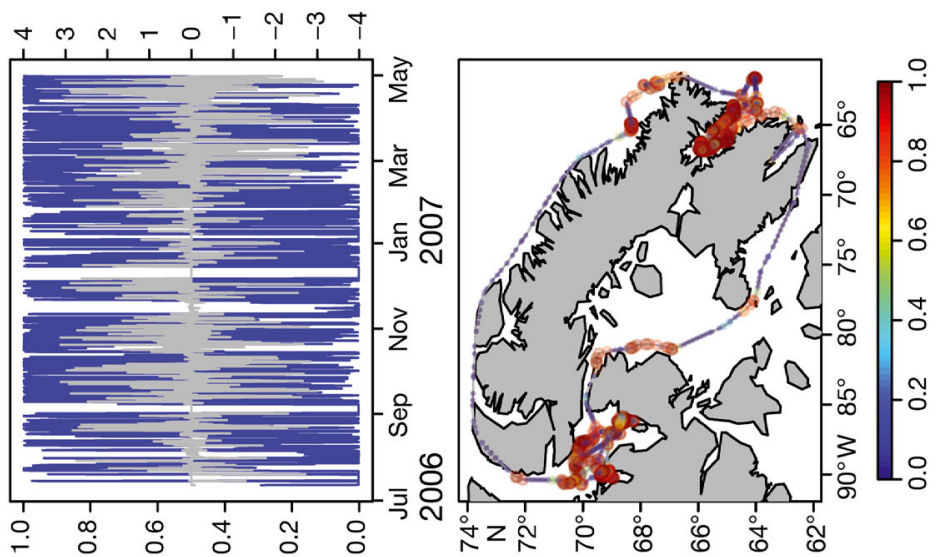

둔

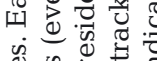

党氠

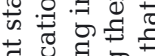

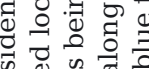

0

चี

त व

矛焉出

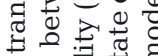

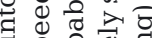

응 웅ㅇㅇ
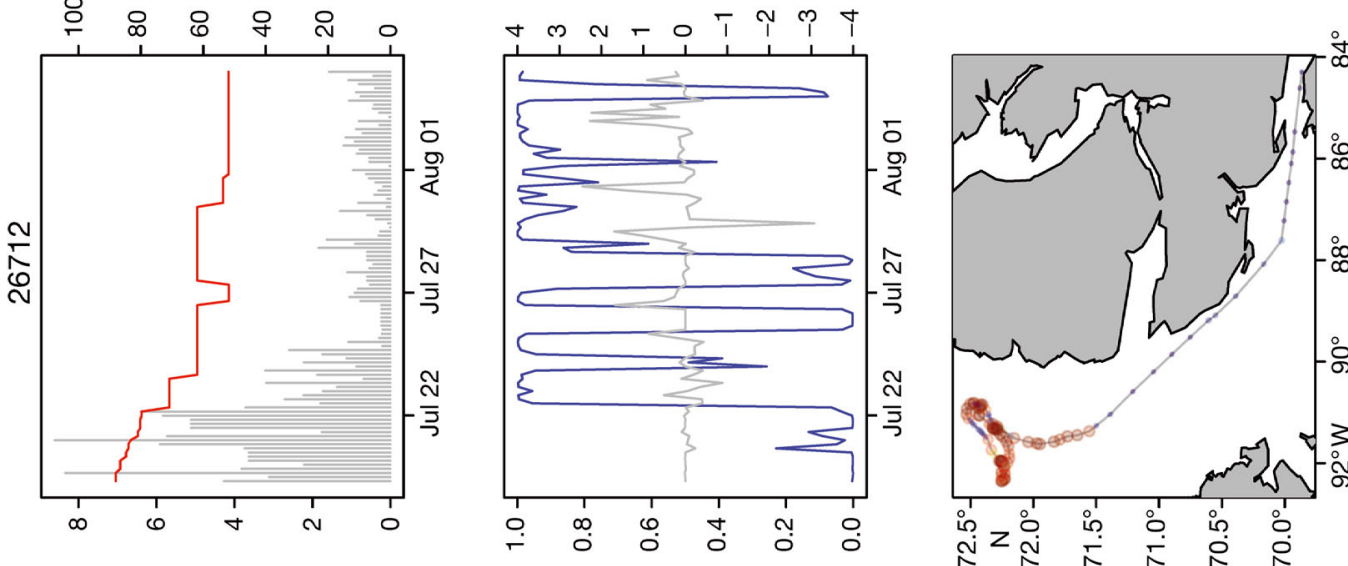

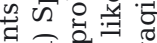

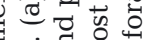

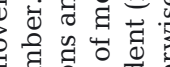

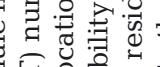

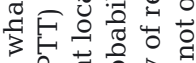

ช

उ.

월

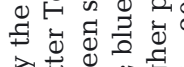

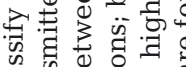

चี ฮै

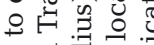

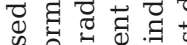
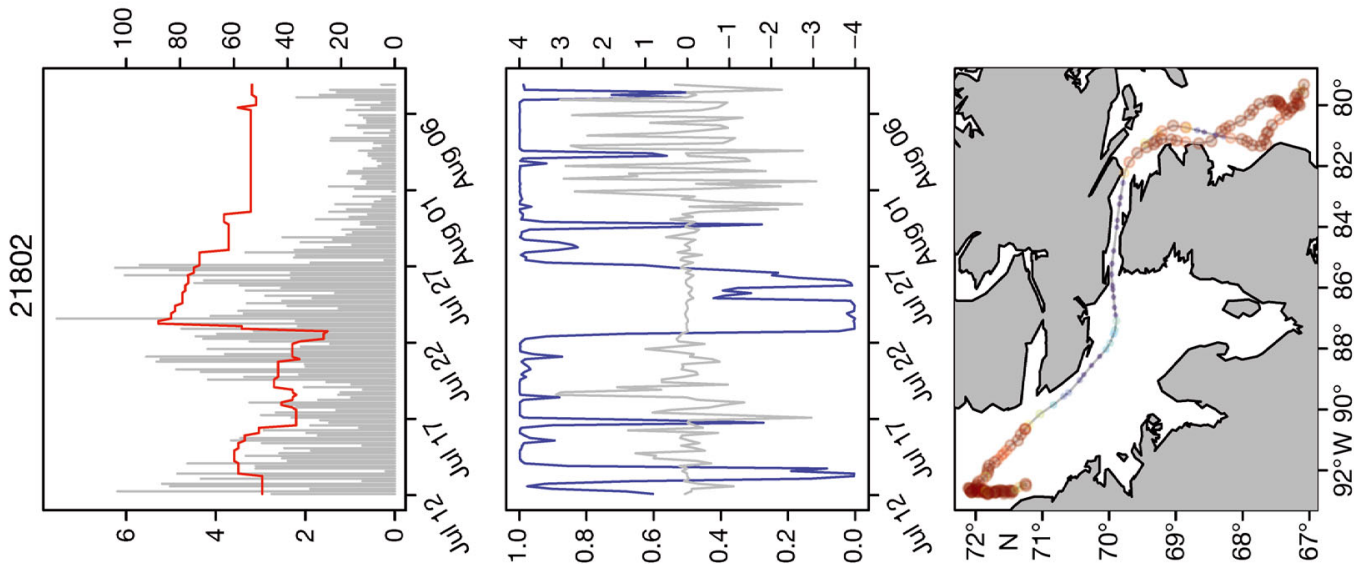

党

$\sum_{1} \sigma_{0} 0$

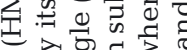

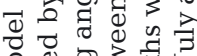

엽.

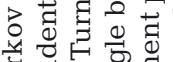

ब 0 व

द्व $\frac{1}{3} \cdot$ 舟

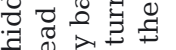

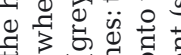

뎡

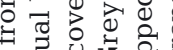

응 우요

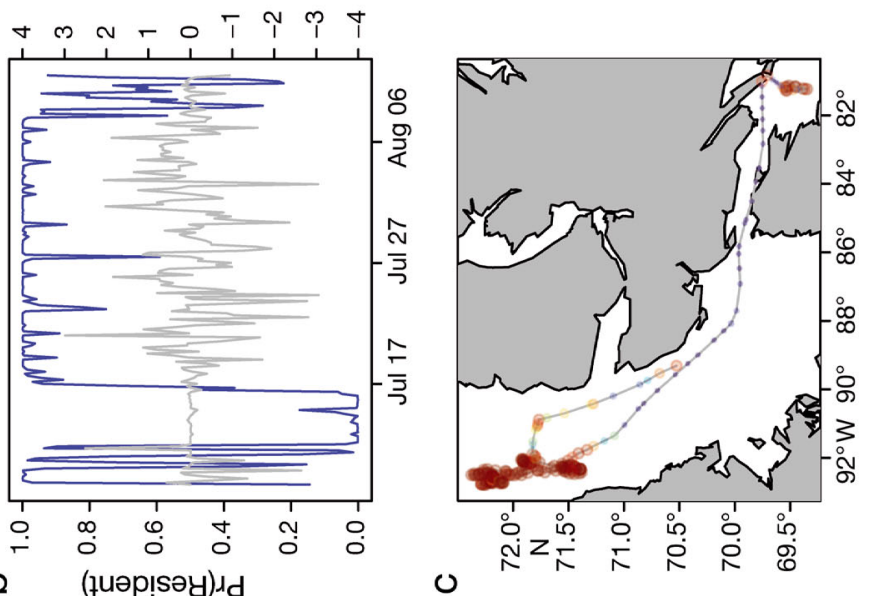

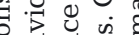

:

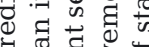

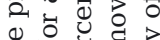

范声

ชิ

ช 0

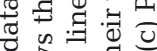

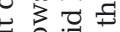

究

겨 잉 $\frac{0}{\sigma}$

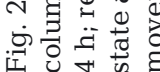


Table 2. Mean percent sea-ice cover $( \pm \mathrm{SD})$ during resident and transient modes for the 4 whales included in the hidden Markov model. PTT $=$ Platform Transmitter Terminal $; \mathrm{n}=$ number of $4 \mathrm{~h}$ time steps analyzed for the periods in resident and transient mode, respectively; FB = Foxe Basin $;$ CS = Cumberland Sound $;$ GB = Gulf of Boothia $;$ DS = Davis Strait

\begin{tabular}{|c|c|c|c|c|c|c|c|}
\hline \multirow[t]{2}{*}{ PTT no. } & \multicolumn{4}{|c|}{ Resident mode- } & \multicolumn{3}{|c|}{ - Transient mode } \\
\hline & Location & $\mathrm{n}$ & Dates & $\begin{array}{l}\text { Mean ice } \\
\text { cover (\%) }\end{array}$ & $\mathrm{n}$ & Dates & $\begin{array}{l}\text { Mean ice } \\
\text { cover }(\%)\end{array}$ \\
\hline \multirow[t]{2}{*}{20167} & $\mathrm{FB}$ & 14 & 8-11 Jul & $39.6( \pm 9.9)$ & 35 & $12-16 \mathrm{Jul}$ & $80.1( \pm 24.3)$ \\
\hline & GB & 146 & 16 Jul-10 Aug & $61.3( \pm 8.8)$ & 6 & 10-11 Aug & $53.9( \pm 5.5)$ \\
\hline \multirow[t]{2}{*}{21802} & $\mathrm{FB}$ & 58 & $12-22 \mathrm{Jul}$ & $44.3( \pm 9.5)$ & 5 & $13 \mathrm{Jul}$ & $54.7( \pm 4.9)$ \\
\hline & GB & 69 & 26 Jul-7 Aug & $57.1( \pm 6.1)$ & 25 & $22-26 \mathrm{Jul}$ & $75.9( \pm 12.8)$ \\
\hline \multirow[t]{2}{*}{26712} & GB & 18 & $22-25 \mathrm{Jul}$ & $65.4( \pm 4.5)$ & 18 & $19-22 \mathrm{Jul}$ & $73.7( \pm 11.5)$ \\
\hline & GB & 44 & 28 Jul-4 Aug & $54.8( \pm 4.4)$ & 14 & $25-28 \mathrm{Jul}$ & $61.3( \pm 2.7)$ \\
\hline \multirow[t]{6}{*}{$66353^{\mathrm{a}}$} & $\mathrm{CS}$ & 31 & 22-27 Jul & $8.6( \pm 5.2)$ & 62 & 12-22 Jul & $17.8( \pm 5.1)$ \\
\hline & $\mathrm{FB}$ & 13 & 9-11Aug & $12.3( \pm 3.3)$ & 76 & 28 Jul-9 Aug & $0.1( \pm 0.9)$ \\
\hline & FB & 39 & 15-25 Aug & $43.3( \pm 5.2)$ & 27 & 11-15 Aug & $49.5( \pm 21.4)$ \\
\hline & GB & 250 & $8 \mathrm{Sep}-11 \mathrm{Nov}$ & $44.4( \pm 19.7)$ & 80 & 26 Aug-9 Sep & $35.2( \pm 13.7)$ \\
\hline & DS & 25 & 28 Nov-4 Dec & $90.7( \pm 4.7)$ & 90 & $17 \mathrm{Sep}-5 \mathrm{Nov}$ & $45.9( \pm 16.7)$ \\
\hline & DS & 14 & 21-24 Dec & $91.6( \pm 2.3)$ & 209 & 12 Nov-30 Dec & $86.8( \pm 11.2)$ \\
\hline
\end{tabular}

${ }^{a}$ Not all the data are presented due to a mix of resident and transient behaviour within CS from 1 January to 1 May 2007

(Fig. 2a, Table 2). The whale returned to CS in early January and stayed within CS all winter until the last day of transmission (1 May 2007) (Fig. 2c). The average ice cover in CS during this second period of residency was $78 \%$.

\section{Dive profiles}

Diving depth was generally shallow in the 7 tagged individuals. Over $90 \%$ of dives were at depths of $50 \mathrm{~m}$ or less, including 70 to $80 \%$ within $20 \mathrm{~m}$ from the surface. The 4 whales tagged in FB concentrated their diving activity above $16 \mathrm{~m}$, while the $3 \mathrm{CS}$ whales tended to make more use of the 16 to $20 \mathrm{~m}$ depth stratum. The immature female (26712) tagged in FB made the deepest dives (>350 m) and was the individual diving the most regularly at depths below $16 \mathrm{~m}$. These occasional deep dives occurred in the northern part of GB where the bathymetry is generally deep (500 m) for the Canadian Arctic Archipelago (AMSA 2009).

The intense use of near-surface depths by bowhead whales was reflected in dive duration, as dives of $6 \mathrm{~min}$ or less comprised 74 to $100 \%$ of the dive record in 6 of the 7 individuals. This tendency was particularly striking in CS individuals, which had over $60 \%$ of their dives lasting $1 \mathrm{~min}$ or less. The one exception to this general pattern was the immature female (26712) tagged in FB, nearly $50 \%$ of whose dives lasted longer than $6 \mathrm{~min}$, including $6 \%$ of dives $>15$ min.

\section{Diving behaviour during resident and transient modes}

Of the 4 whales whose movement patterns were classified into resident versus transient modes, only 3 provided dive data for both modes (Table 1). In general, these 3 whales dived deeper during transit than during residency (Fig. 3a). Indeed, behavioural state was a significant term in the 4 most parsimonious models for average and maximum diving depth (average diving depth: $F_{1282}=5.77$; maximum diving depth: $F_{1,280}=19.72 ; \mathrm{p}<0.05$ both cases). Inter-individual effects were included in the 2 best-ranking models for maximum dive depth $\left(F_{2,280}=5.67, \mathrm{p}<\right.$ 0.001), but only in the second best-ranked model for average dive depth. Time of day was not a significant factor in the best-ranking models for average or maximum diving depth, nor was it a significant predictor of behaviour in any of the candidate models ( $p>0.05$, for all candidate models). Mean diving depth was usually between 20 and $50 \mathrm{~m}$ while in transit, whereas it was often shallower during residency mode (especially within GB) for the 3 whales (Fig. 3b).

\section{DISCUSSION}

We were able to determine the location and characteristics of what appears to be a summer feeding area in the Canadian eastern Arctic for 4 whales from the EC-WG bowhead whale population. During sum- 
a)
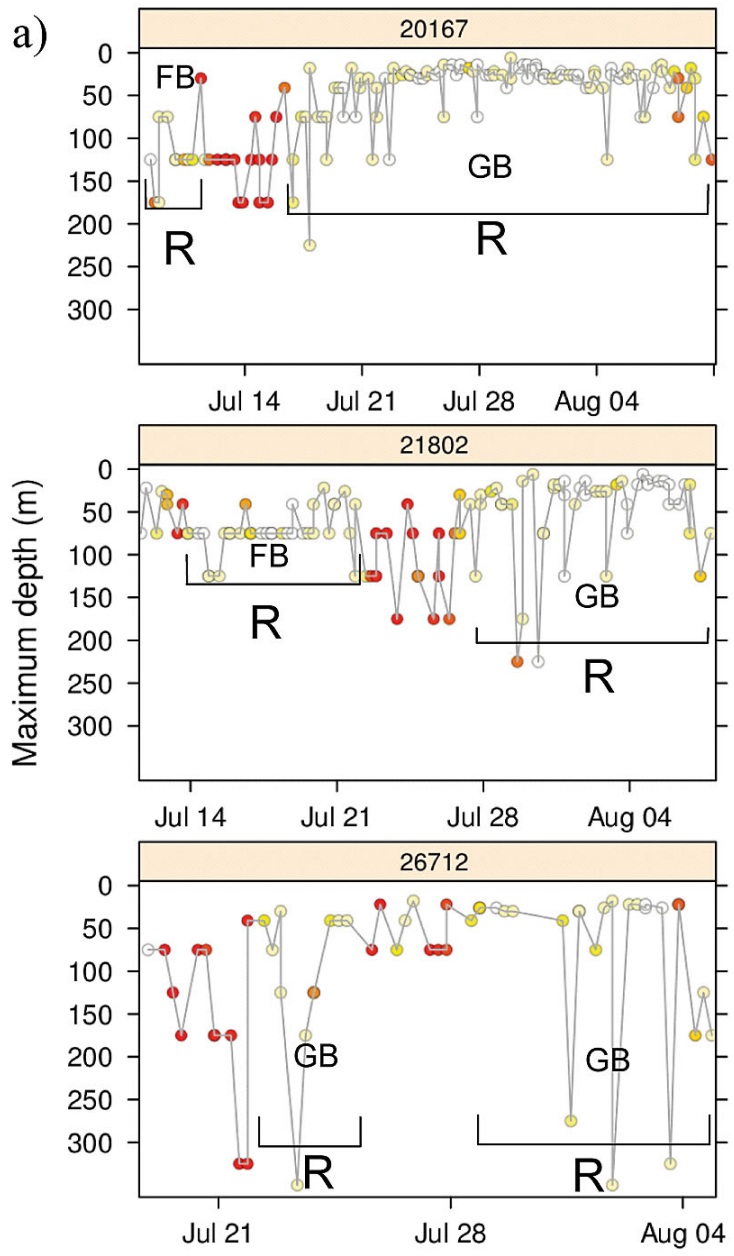

b)
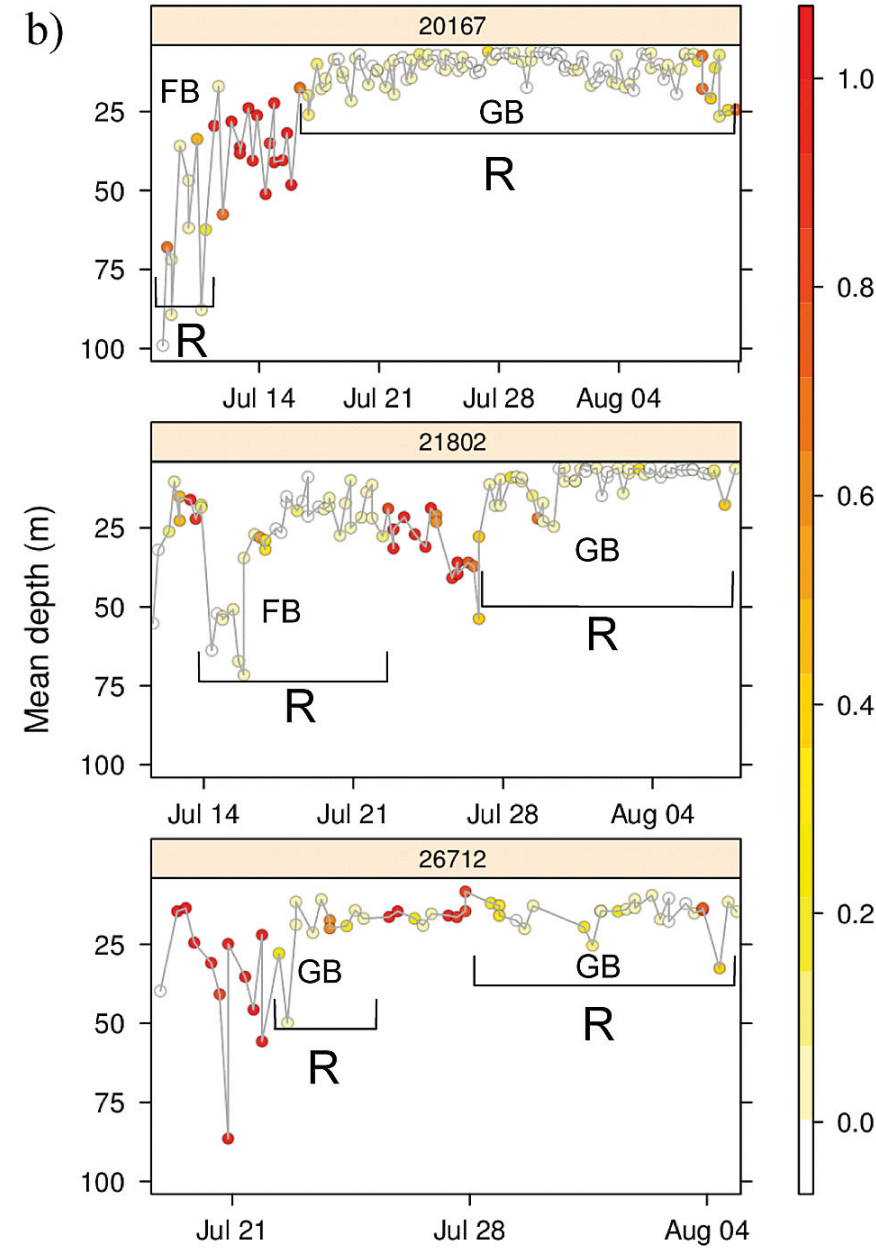

Fig. 3. Temporal changes in (a) maximum and (b) mean dive depth as a function of behavioural mode according to the probability of state. Values in the right-hand colour bar are probability, from 0 to 1, of being in transient state; red represents transit mode and yellow/white resident mode. $\mathrm{R}=$ resident mode; FB = Foxe Basin; $\mathrm{GB}=$ Gulf of Boothia. Dates are for 2003

mer, and regardless of tagging region, resident behaviour occurred mostly in the GB, and while in this mode and area, whales spent most of their time close to the surface. Bowhead whales were associated with sea ice during both transit and residency modes, although ice coverage was generally less extensive in areas where residency occurred compared to areas used for transit. The similarity in state prediction between models with and without ice probably reflects our limited ability to model effects of ice on movement patterns with current sample size rather than a lack of influence of ice on bowhead whale behavior. A much larger sample size will be needed to properly quantify the effect of environmental factors such as sea ice density on their behavior.

Residency mode is assumed to include foraging, as predators, especially those like bowhead whales, will typically decrease travel speed and increase turning angles when they come across an aggregation of prey (Jonsen et al. 2005, Bailey et al. 2009, Patterson et al. 2009). We presume that the major proportion of residency is linked to feeding, given the suspected importance of this behaviour during summer (Burns et al. 1992). However, we acknowledge that not all residency may be associated with active foraging, as it may include other behaviours such as nursing in cow-calf pairs or social activities.

In this study, we have used the output of the HMM for the analysis of dive data. This reflects a limitation of current state-space and other methods which tend to analyze the horizontal components of movement in isolation. This highlights a need to build behavioural analysis approaches which can use horizontal and vertical movement data simultaneously. Because of the small number of individuals included in the 
analysis, we deliberately chose to keep the models simple. However, we note that, with a more extensive data set, covariates such as water depth and ice concentration could be included directly in the HMMs rather than as a linear correlate to behavioral switching as done here for ice concentration (Patterson et al. 2009). For the present study the intent of using the HMMs was exploratory rather than inferential. Nonetheless, the results suggest that with more extensive data, these methods could be used successfully to explore the links between habitat variables and movement and foraging behaviour of bowhead whales.

GB was a common summer feeding area for all 4 whales, regardless of tagging region, indicating that there must be adequate food resources, e.g. dense aggregations of zooplankton prey at that time of the year in this particular area. Data from a biogeochemical mooring deployed in eastern Bellot Strait, between Boothia Peninsula and Somerset Island, from October 2007 to September 2009 suggest substantial primary production from strong water column mixing and enhanced availability of nutrients induced by strong tidal movements in the strait ( $\mathrm{S}$. Vagle pers. comm.). This could partly explain the aggregation of marine life in the eastern Bellot Strait region including sea birds, seals and walruses (Stirling 1997), although local productivity is currently unknown.

Predator avoidance is possibly another reason why bowhead whales remained within GB in association with sea ice during summer. Killer whale Orcinus orca sightings in the Arctic have become more frequent with warmer Arctic summers and increased open water areas (Ferguson et al. 2010b), including the northern portion of GB (Matthews et al. 2011). Calves and immature whales are likely more vulnerable to killer whale predation, as most documented cases in FB involved bowhead whale calves (DFO 2008).

Diving patterns were not related to time of day, which suggests that deep dives were unrelated to vertical movements of zooplankton prey. Our ability to detect such an effect may be limited by the constraints imposed by the instruments, which allowed the collection of only histogram summary data during 4 periods of equal duration during the day. Continuous data, or a subsample thereof, might be a better test for the existence of a cyclical pattern in diving behaviour. In southern latitudes, the vast majority of zooplankton taxa perform diel vertical migration (DVM) (Longhurst 1976). As a result, several planktivorous whale species adjust their foraging behav- iour accordingly and track the vertical migrations of their prey (Croll et al. 2005, Doniol-Valcroze et al. 2011). However, summer months at higher latitudes are characterized by up to $24 \mathrm{~h}$ of daylight and zooplankton do not perform DVM (Blachowiak-Samolyk et al. 2006), their vertical distribution probably being mostly influenced by sea ice cover and hydrodynamic factors (Buchanan \& Haney 1980).

Several studies of the vertical distribution of Arctic zooplankton species revealed that maximum densities of key herbivorous calanoid copepods (i.e. Calanus hyperboreus and C. glacialis) were usually within 0 to $50 \mathrm{~m}$ from the surface during summer (Tande \& Bamstedt 1985, Hassel 1986, BlachowiakSamolyk et al. 2006). These 2 pelagic and herbivorous copepod species, along with $C$. finmarchicus (in areas where there is an influence of Atlantic waters, such as in Baffin Bay), are believed to be important prey of the EC-WG bowhead whale population (Finley 2001, Laidre et al. 2007). The strong preference of bowhead whales for depths between 8 and $20 \mathrm{~m}$ is consistent with intense filter-feeding on shallow zooplankton prey such as calanoid copepods.

In the marine environment, the seasonal variability and patchiness of food is a problem that predators need to overcome in order to fulfill their energetic requirements (Bluhm \& Gradiger 2008). Baumgartner et al. (2003) found a strong correlation between the average diving depth of North Atlantic right whales Eubalaena glacialis and peak abundance of its preferred prey (Calanus finmarchicus). The same pattern was observed for bowhead whales in springtime in Disko Bay, Greenland, where all foraging dives were to the bottom where diapausing $C$. finmarchicus densities were the highest (Laidre et al. 2007).

Laidre et al. (2007) studied the dives of 14 individuals in Disko Bay, Greenland, and their findings describe deeper $(400 \mathrm{~m})$ maximum dives, and much deeper mean and maximum dive depths of $53 \pm 35$ to $109 \pm 41 \mathrm{~m}$, respectively. Similar findings were obtained from bowhead whales tagged elsewhere in Greenland (Simon et al. 2009). These differences could be due to the age of the study animals, as we uniquely observed deep diving in an immature female, the study duration, as the Greenland records tended to be short (a few hours to a few days), or seasonal differences. Feeding behaviour may vary seasonally and geographically depending on prey species availability and concentration. Both Greenland studies took place in the spring, when potential zooplankton prey species distribution is usually much more vertically expanded than in summer months (Hansen et al. 1996). 
Our findings are limited to a small number of individuals from the EC-WG bowhead whale population, but provide meaningful information for the conservation of this population. Despite our small sample size, we were able to demonstrate that bowhead whales originating from regions separated by several hundreds of kilometers converged into an area in the northern part of the GB, likely to forage intensively during summer on near-surface zooplankton aggregations. In the context of the upcoming industrial development of the Arctic, every effort should therefore be made to maintain the integrity of this ecosystem.

Acknowledgements. We thank the communities of Igloolik and Pangnirtung for their assistance with tagging efforts. We express special thanks to Bill Williams and Svein Vagle for their information about the mooring experiment in Bellot Strait. Tagging procedures were approved by the DFO Freshwater Institute Animal Care Committee (AUP\# FWIACC-2002, 3, 4, 5, 6-007) and permitted under DFO License to Fish for Scientific Purposes \#S-02/03to05/06-1019-NU. This study was funded by Fisheries and Oceans Canada, the Nunavut Wildlife Management Board, the Nunavut Implementation Fund, and a NSERC Discovery Grant to S.H.F.

\section{LITERATURE CITED}

AMSA (2009) Arctic marine shipping assessment. Arctic Marine Shipping Assessment 2009 Report. Arctic Council, Tromsø

Bailey H, Mate BR, Palacios DM, Irvine L, Bograd SJ, Costa DP (2009) Behavioural estimation of blue whale movements in the Northeast Pacific from state-space model analysis of satellite tracks. Endang Species Res 10: 93-106

Baumgartner MF, Cole TVN, Campbell RG, Teegarden GJ, Durbin EG (2003) Association between North Atlantic right whales and their prey, Calanus finmarchicus, over diel and tidal time scales. Mar Ecol Prog Ser 264:155-166

Bell KNI (2008) Analysing cycles in biology and medicinea practical introduction to circular variables and periodic regression, 2nd edn. Razorbill Press, St. John's

Benoit-Bird KJ, Dahood AD, Wursig B (2009) Using active acoustics to compare lunar effects on predator-prey behavior in two marine mammal species. Mar Ecol Prog Ser 395:119-135

Blachowiak-Samolyk K, Kwasniewski S, Richardson K, Dmoch K and others (2006) Arctic zooplankton do not perform diel vertical migration (DVM) during periods of midnight sun. Mar Ecol Prog Ser 308:101-116

Bluhm BA, Gradinger R (2008) Regional variability in food availability for Arctic marine mammals. Ecol Appl 18: S77-S96

Buchanan C, Haney J (1980) Vertical migrations of zooplankton in the Arctic: a test of the environmental controls. In: Kerfoot WC (ed) Evolution and ecology of zooplankton communities. University Press of New England, Hanover, NH, p 69-79

Burnham KP, Anderson DR (2002) Model selection and mul- timodel inference: a practical information-theoretic approach, 2nd edn. Springer, Fort Collins, CO

Burns JJ, Montague JJ, Cowles CJ (1992) The bowhead whale. The Society for Marine Mammalogy Spec Publ No. 2, Allen Press, Lawrence, KS

Cosens SE, Innes S (2000) Distribution and numbers of bowhead whales (Balaena mysticetus) in northwestern Hudson Bay in August, 1995. Arctic 53:36-41

Cosens SE, Qarnukaq T, Parker B, Dueck LP, Anardjuak B (1997) The distribution and numbers of bowhead whales, Balaena mysticetus, in northern Foxe Basin in 1994. Can Field Nat 111:381-388

COSEWIC (2009) COSEWIC assessment and update status report on the bowhead whale (Balaena mysticetus), Bering-Chukchi-Beaufort population and Eastern Canada-West Greenland population, in Canada. Committee on the Status of Endangered Wildlife in Canada, Ottawa

Croll DA, Marinovic B, Benson S, Chavez FP, Black N, Ternullo R, Tershy BR (2005) From wind to whales: trophic links in a coastal upwelling system. Mar Ecol Prog Ser 289:117-130

DFO (Fisheries and Oceans Canada) (2008) Assessment of eastern Arctic bowhead whales (Balaena mysticetus). Science Advisory Report 2007/053 DFO Canadian Science Advisory Secretariat, Ottawa

Doniol-Valcroze T, Lesage V, Giard J, Michaud R (2011) Optimal foraging theory predicts diving and feeding strategies of the largest marine predator. Behav Ecol 22: 880-888

Dueck LP Richard P, Cosens SE (2007) A review and reanalysis of Cosens et al. (2006) aerial survey assessment of bowhead whale abundance for the eastern Canadian Arctic. DFO Canadian Science Advisory Secretariat. Science Advisory Report 2007/080

Dyke AS, Hooper J, Savelle JM (1996) A history of sea ice in the Canadian Arctic Archipelago based on postglacial remains of the bowhead whale (Balaena mysticetus). Arctic 49:235-255

Ferguson SH, Dueck L, Loseto LL, Luque SP (2010a) Bowhead whale Balaena mysticetus seasonal selection of sea ice. Mar Ecol Prog Ser 411:285-297

Ferguson SH, Higdon JW, Chmelnitsky EG (2010b) The rise of killer whales as a major Arctic predator. In: Ferguson SH, Loseto LL, Mallory ML (eds) A little less Arctic: top predators in the world's largest northern inland sea, Hudson Bay. Springer, New York, NY, p 117-136

Finley KJ (2001) Natural history and conservation of the Greenland whale, or bowhead, in the Northwest Atlantic. Arctic 54:55-76

Gagnon AS, Gough WA (2005) Climate change scenarios for the Hudson Bay region: an intermodel comparison. Clim Change 69:269-297

George JC, Bada J, Zeh J, Scott L, Brown SE, O'Hara T, Suydam R (1999) Age and growth estimates of bowhead whales (Balaena mysticetus) via aspartic acid racemization. Can J Zool 77:571-580

Gosselin M, Levasseur M, Wheeler PA, Horner RA, Booth BC (1997) New measurements of phytoplankton and ice algal production in the Arctic Ocean. Deep-Sea Res II 44: 1623-1644

Greene CH, Pershing AJ (2007) Climate drives sea change. Science 315:1084-1085

Hansen B, Christiansen S, Pedersen G (1996) Plankton dynamics in the marginal ice zone of the central Barents 
Sea during spring: carbon flow and structure of the grazer food chain. Polar Biol 16:115-128

Hassel A (1986) Seasonal changes in zooplankton composition in the Barents Sea, with special attention to Calanus spp. (Copepoda). J Plankton Res 8:329-339

Heide-Jørgensen MP, Laidre KL, Wig O, Jensen MV and others (2003) From Greenland to Canada in ten days: tracks of bowhead whales, Balaena mysticetus, across Baffin Bay. Arctic 56:21-31

Heide-Jørgensen MP, Laidre KL, Borchers D, Samarra F, Stern H (2007) Increasing abundance of bowhead whales in West Greenland. Biol Lett 3:577-580

Higdon JW, Ferguson SH (2009) Loss of Arctic sea ice causing punctuated change in sightings of killer whales (Orcinus orca) over the past century. Ecol Appl 19: 1365-1375

Higdon JW, Ferguson SH (2010) Past, present, and future for bowhead whales (Balaena mysticetus) in northwest Hudson Bay. In: Ferguson SH, Loseto LL, Mallory ML (eds) A little less Arctic: top predators in the world's largest northern inland sea, Hudson Bay. Springer, New York, NY, p 159-177

International Whaling Commission (IWC) (2009) Report of the scientific committee. J Cetacean Res Manag 11 (Suppl):169-192

IPCC (Intergovernmental Panel on Climate Change) (2007) Climate change 2007: the physical science basis. Contribution of Working Group I to the fourth assessment report of the Intergovernmental Panel on Climate Change. Cambridge University Press, Cambridge

Jonsen ID, Flemming JM, Myers RA (2005) Robust state-space modeling of animal movement data. Ecology 86:2874-2880

Kooyman GL, Ponganis PJ (1998) The physiological basis of diving to depth: birds and mammals. Annu Rev Physiol 60:19-32

Koski WR, Heide-Jørgensen MP, Laidre KL (2006) Winter abundance of bowhead whales, Balaena mysticetus, in the Hudson Strait, March 1981. J Cetacean Res Manag 8: 139-144

Kovacs KM, Lydersen C, Overland JE, Moore SE (2010) Impacts of changing sea-ice conditions on Arctic marine mammals. Mar Biodiv 41:181-194

Laidre KL, Heide-Jørgensen MP, Gissel Nielsen T (2007) Role of the bowhead whale as a predator in West Greenland. Mar Ecol Prog Ser 346:285-297

Lee SH, Schell DM, McDonald TL, Richardson WJ (2005) Regional and seasonal feeding by bowhead whales Balaena mysticetus as indicated by stable isotope ratios. Mar Ecol Prog Ser 285:271-287

Longhurst AR (1976) Vertical migration. In: Cushing DH, Walsh JJ (eds) The ecology of the seas. WB Saunders, Philadelphia, PA, p 116-137

Lowry LF, Sheffield G, George JC (2004) Bowhead whale feeding in the Alaskan Beaufort Sea based on stomach content analysis. J Cet Res Manag 6:215-223

Matthews CJD, Luque S, Petersen SD, Andrews RD, Ferguson SH (2011) Satellite tracking of a killer whale (Orcinus orca) in the eastern Canadian Arctic documents ice avoidance and rapid, long-distance movement into the North Atlantic. Polar Biol 34:1091-1096

Moore SE, Reeves RR (1993) Distribution and movement. In: Burns JJ, Montague JJ, Cowles CJ (eds) The bowhead whale. Society for Marine Mammalogy Spec Publ No. 2, Allen Press, Lawrence, KS, p 313-386

Neibauer HJ, Schell DM (1993). Physical environment of the Bering Sea population. In: Burns JJ, Montague JJ, Cowles CJ (eds) The bowhead whale. Society for Marine Mammalogy Spec Publ No. 2, Allen Press, Lawrence, KS, p 23-44

Nowak RM, Walker EP (2003) Walker's marine mammals of the world. John Hopkins University Press, Baltimore, MD

Patterson TA, Basson M, Bravington MV, Gunn JS (2009) Classifying movement behaviour in relation to environmental conditions using hidden Markov models. J Anim Ecol 78:1113-1123

> Patterson TA, McConnell BJ, Fedak MA, Bravington MV, Hindell MA (2010) Using GPS data to evaluate the accuracy of state-space methods for correction of Argos satellite telemetry error. Ecology 91:273-285

Pershing AJ, Record NR, Monger BC, Mayo CA and others (2009) Model-based estimates of right whale habitat use in the Gulf of Maine. Mar Ecol Prog Ser 378:245-257

Pinheiro J, Bates D, DebRoy S, Sarkar D, R Development Core Team (2011) nlme: linear and nonlinear mixed effects models. R package version 3.1-102. www.Rproject.org

> Pomerleau C, Ferguson SH, Wojciech W (2011) Stomach contents of bowhead whales (Balaena mysticetus) from four locations in the Canadian Arctic. Polar Biol 34: $615-620$

Reeves RR, Heide-Jørgensen MP (1996) Recent status of bowhead whales, Balaena mysticetus, in the wintering grounds off West Greenland. Polar Res 15:115-125

> Reynolds RW (1988) A real-time global sea surface temperature analysis. J Clim 1:75-86

Simon M, Johnson M, Tyack P, Madsen PT (2009) Behaviour and kinematics of continuous ramfiltration in bowheadwhales (Balaena mysticetus). Proc R Soc Lond B Biol Sci 276:3819-3828

- Stirling I (1997) The importance of polynyas, ice edges, and leads to marine mammals and birds. J Mar Syst 10:9-21

> Tande KS, Bamstedt U (1985) Grazing rates of the copepods Calanus glacialis (Jaschnov) and C. finmarchicus (Gunnerus) in arctic waters of the Barents Sea. Mar Biol 87: 251-258

Woodby DA, Botkin DB (1993) Stock sizes prior to commercial whaling. In: Burns JJ, Montague JJ, Cowles CJ (eds) The bowhead whale. Society for Marine Mammalogy Spec Publ No. 2, Allen Press, Lawrence, KS, p 387-407 


\section{Appendix 1}

Table A1. Summary of ranking of 8 fitted models for average diving depth and maximum diving depth. Model parameters follow the description of the full model in 'Materials and methods: Analysis of diving behaviour'). AICc $=$ secondorder Akaike Information Criterion

\begin{tabular}{|c|c|c|}
\hline Parameters in model & $\mathrm{AICc}$ & $\triangle \mathrm{AICc}$ \\
\hline \multicolumn{3}{|l|}{ Average diving depth } \\
\hline$\beta_{1}, \beta_{5}$ & 2073 & 0 \\
\hline$\beta_{1}, \beta_{2}, \beta_{3}, \beta_{5}$ & 2076 & 2.889 \\
\hline$\beta_{1}$ & 2076 & 3.213 \\
\hline$\beta_{1}, \beta_{4}, \beta_{5}$ & 2077 & 3.908 \\
\hline$\beta_{1}, \beta_{2}, \beta_{3}$ & 2079 & 5.765 \\
\hline$\beta_{1}, \beta_{2}, \beta_{3}, \beta_{4}, \beta_{5}$ & 2080 & 6.859 \\
\hline$\beta_{1}, \beta_{4}$ & 2080 & 7.190 \\
\hline$\beta_{1}, \beta_{2}, \beta_{3}, \beta_{4}$ & 2083 & 9.803 \\
\hline \multicolumn{3}{|c|}{ Maximum diving depth } \\
\hline$\beta_{1}, \beta_{4}, \beta_{5}$ & 3098 & 0 \\
\hline$\beta_{1}, \beta_{2}, \beta_{3}, \beta_{4}, \beta_{5}$ & 3098 & 0.1183 \\
\hline$\beta_{1}, \beta_{2}, \beta_{3}, \beta_{5}$ & 3100 & 2.0280 \\
\hline$\beta_{1}, \beta_{5}$ & 3100 & 2.2730 \\
\hline$\beta_{1}, \beta_{2}, \beta_{3}, \beta_{4}$ & 3109 & 11.0000 \\
\hline$\beta_{1}, \beta_{4}$ & 3110 & 12.6600 \\
\hline$\beta_{1}, \beta_{2}, \beta_{3}$ & 3112 & 13.8500 \\
\hline$\beta_{1}$ & 3114 & 16.0000 \\
\hline
\end{tabular}

Editorial responsibility: Sascha Hooker,

Fife, UK
Submitted: December 22, 2010; Accepted: August 3, 2011 Proofs received from author(s): October 19, 2011 